\title{
Krzysztof Maślanka
}

\section{ORCID 0000-0003-4010-4093}

Instytut Historii Nauki imienia Ludwika i Aleksandra Birkenmajerów

Polskiej Akademii Nauk (Warszawa - Kraków, Polska)

krzysiek2357@gmail.com

\section{Piotr Flin (1945-2018) - wspomnienie}

\author{
Abstrakt \\ W artykule omówiono zwięźle sylwetkę i dorobek naukowy zmar- \\ łego niedawno astronoma dra hab. Piotra Flina. \\ Słowa kluczowe: Piotr Flin, historia astronomii w Krakowie, kosmologia \\ obserwacyjna, Pole Jagiellońskie, problem grupowania galaktyk
}

\section{Piotr Flin (1945-2018) - In Memoriam}

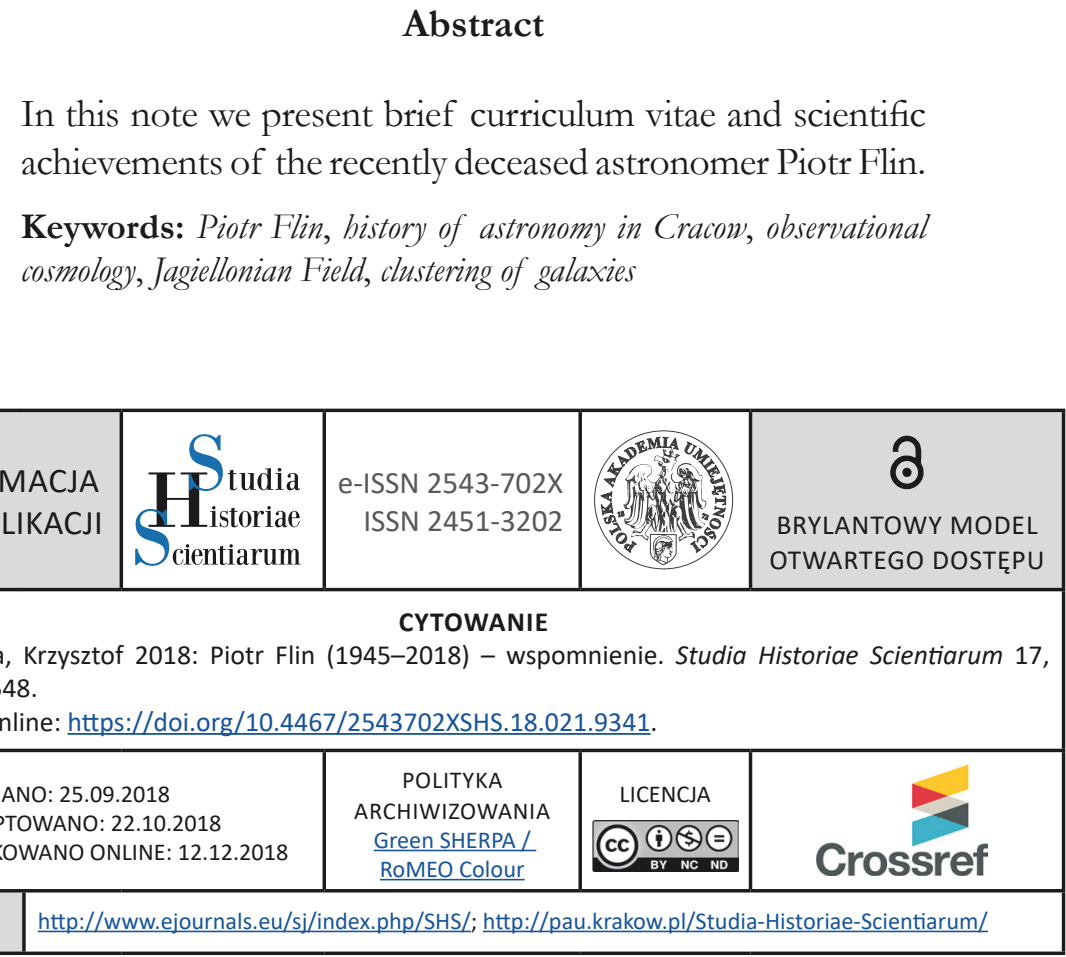




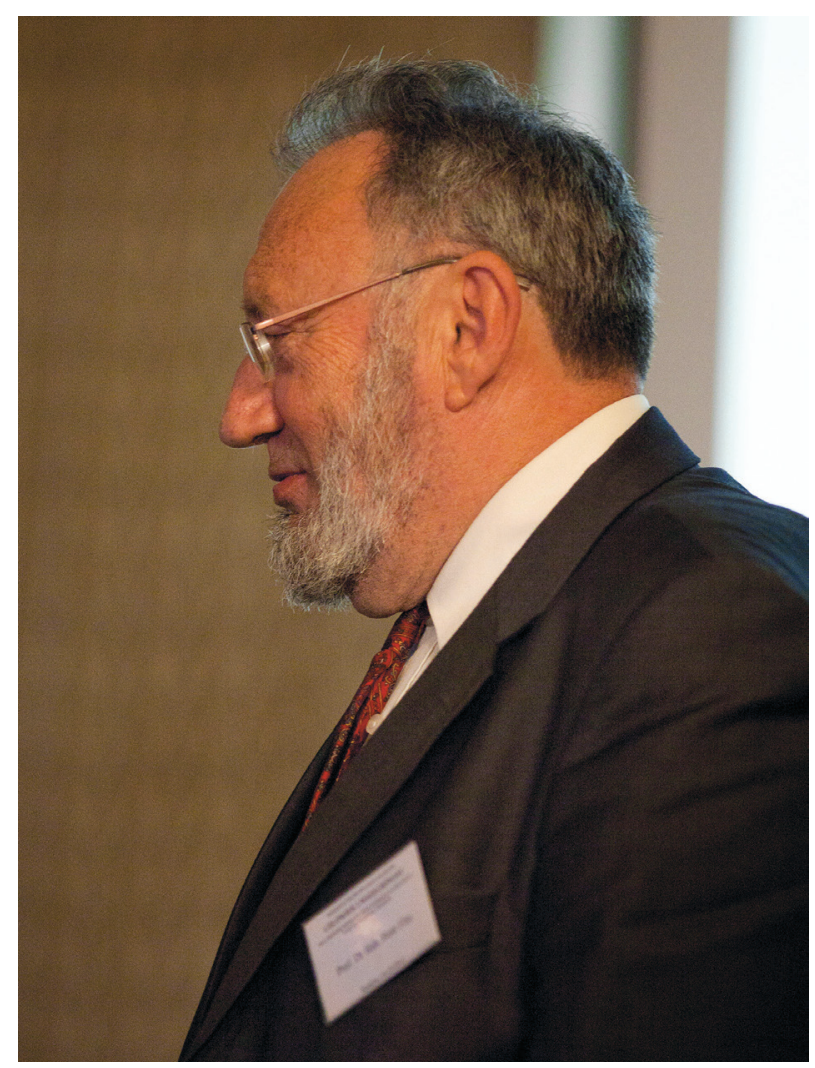

Ryc. 1. Piotr Flin w czasie referatu „Własności gromad galaktyk”, na sesji naukowej Człowiek $i$ W szechświat zorganizowanej przez dr. Bogdana Wszołka dla uhonorowania ks. prof. Konrada Rudnickiego z okazji 85. rocznicy urodzin, Kraków, 15 X 2011, Collegium Śniadeckiego UJ (dawne Obserwatorium Astronomiczne). Fot. Adam Walanus.

\section{Piotr Flin i Jego najbliższa rodzina}

Urodził się 11 marca 1945 r. w Krakowie. Jego rodzice byli cenionymi artystami. Matką była Stefania Dretler-Flin, z domu Juer (1909-1994). Jej pierwszy mąż, Julian Marian Dretler (1905-1944), lekarz psychiatra $\mathrm{z}$ dużym dorobkiem naukowym, wskutek ciężkim ran odniesionych 8-go sierpnia 1944 w powstaniu warszawskim zmarł kilka dni później, 13-go sierpnia, w powstańczym szpitalu. ${ }^{1}$

${ }^{1}$ Wikipedia 2018a; ResearchGate 2018. 


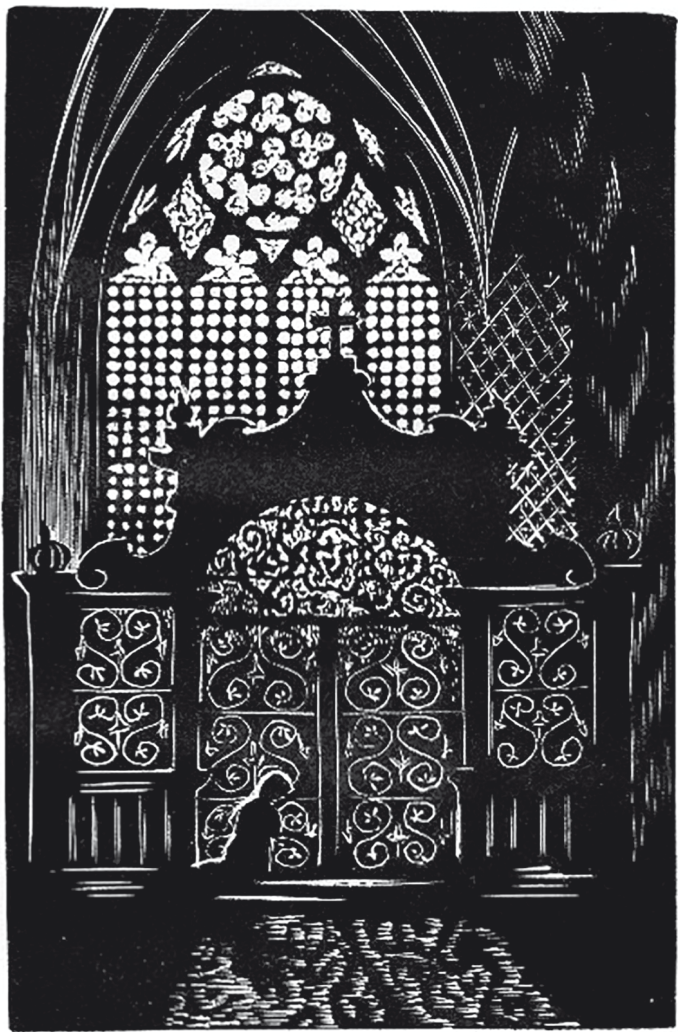

Ryc.2. Stefania Dretler-Flin - Kaplica Pržemienienia Pańskiego w Kościele NMP w Krakowie, drzeworyt z teki „Najpiękniejszy jest Kraków” (1947), ze zbioru rodziny Flinów.

Stefania kształciła się w Krakowie, a później została absolwentką sławnej paryskiej Académie Colarossi. ${ }^{2}$ Debiutowała w roku 1933. Specjalizowała się początkowo w grafice (drzeworyt i linoryt), później w ceramice i rzeźbie figuralnej. Uczestniczyła w Powstaniu Warszawskim. Należała do krakowskiej grupy Dziewięciu Grafików (19471960), która, jako jedna z pierwszych, zainicjowała polskie życie artystyczne po II Wojnie Światowej’3. W 1949 roku grupa ta aktywnie

${ }^{2}$ Szkołę tę ukończyli m.in.: Camille Claudel, Amedeo Modigliani i Alfons Mucha, a z Polaków - Franciszek Siedlecki, Włodzimierz Tetmajer i Stanisław Wyspiański zob. Wikipedia 2018b.

${ }^{3}$ Chrzanowska-Pieńkos, Pieńkos 2001; Krzyżanowska 2014; Wikipedia 2018c. 
włączyła się w nurt zalecanego wtedy odgórnie socrealizmu, ale dopiero po „odwilży” w połowie lat pięćdziesiątych nastąpił znaczący rozkwit twórczości jej członków; powstały liczne prace tworzone w duchu ekspresjonizmu, metafory i abstrakcji. ${ }^{4}$

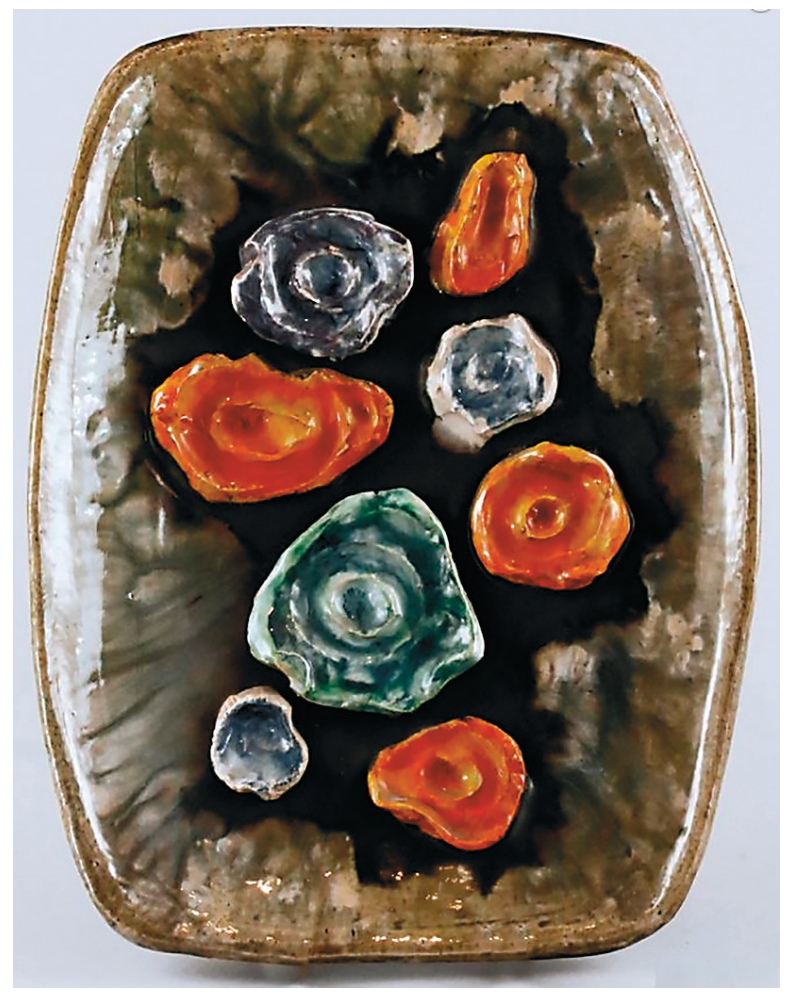

Ryc.3. Zygmunt Flin, Patera dekoracyjna, glinka ceramiczna i szkliwa barwne, $37,5 \times 29,5 \times 4,5 \mathrm{~cm}$, ok. 1960 r., ze zbioru rodziny Flinów.

Ojciec Piotra, Zygmunt Flin (1909-1993), architekt, rzeźbiarz, grafik, ukończył Wydział Architektury Politechniki Lwowskiej. Przed wojna, w latach 1933-1939, uprawial grafikę reklamową. W latach 1943-1945 był więźniem niemieckiego obozu w Oświęcimiu. Od 1954 uczestniczył

${ }^{4}$ Jako bliski sąsiad Piotra pamiętam tę drobną, dystyngowaną starszą panią, gdy jeszcze na początku lat 90. powoli chodziła do sklepu z torbą na kółkach i bardzo starannie, władczym tonem zamawiała towar. 
w wystawach ceramiki i rzeźby w Warszawie, Krakowie i Gdańsku, a także w Pradze (1962), Bolonii (1967) oraz Monachium (1968). Miał kilka wystaw indywidualnych, m.in. w Krakowie (1965, 1973), Katowicach (1970) oraz Warszawie (1966). ${ }^{5}$

O ile wiem, po śmierci rodziców Piotr - nie będąc aktywnym kontynuatorem ich artystycznej profesji - zachował jednak w piwnicy swego domu piec do wypalania ceramiki. Kiedyś wyznał mi tajemniczo: „Mam w piwnicy coś, co powoli mi przetrwać, gdybym stracił pracę”.

\section{Kariera naukowa}

W Uniwersytecie Jagiellońskim Piotr Flin studiował najpierw astronomię (1963-1968), a później fizykę (1969-1972). W roku 1975 obronił pracę doktorska pt. Cechy morfologiczne gromad galaktyke, której promotorem był ceniony w świecie astronom prof. Konrad Rudnicki (1926-2013). ${ }^{6}$ W roku 1991 uzyskał stopień doktora habilitowanego nauk fizycznych w zakresie astronomii w Uniwersytecie Mikołaja Kopernika w Toruniu na podstawie pracy Testowanie teorii powstawania galaktyk $k^{7}$.

W latach 1968-1988 był pracownikiem Obserwatorium Astronomicznego Uniwersytetu Jagiellońskiego. Następnie pracował jako wykładowca w Ośrodku Badań Interdyscyplinarnych przy Wydziale Filozofii Papieskiej Akademii Teologicznej w Krakowie (1988-1991). W latach 1992-1995 był kierownikiem Pracowni Fundamentalnych Problemów Fizyki w Wyższej Szkole Pedagogicznej w Krakowie. W latach 1998-2000 był wykładowcą Papieskiej Akademii Teologicznej w Krakowie.

Od 1993 był profesorem Wyższej Szkoły Pedagogicznej w Kielcach, przekształconej kolejno w Akademię Świętokrzyską i Uniwersytet Jana Kochanowskiego. W 1995 objął kierownictwo Zakładu Astrofizyki w Instytucie Fizyki na Wydziale Matematyczno-Przyrodniczym UJK. Był inicjatorem budowy obserwatorium i planetarium na budynku tego Wydziału przy ulicy Świętokrzyskiej w Kielcach, które zostały ukończone w roku 2003.

\footnotetext{
${ }^{5}$ Artinfo.pl 2018.

${ }^{6}$ Naukowe ośrodki astronomiczne w kraju 1976.

7 Nauka Polska. Ludzie Nauki 2018.
} 


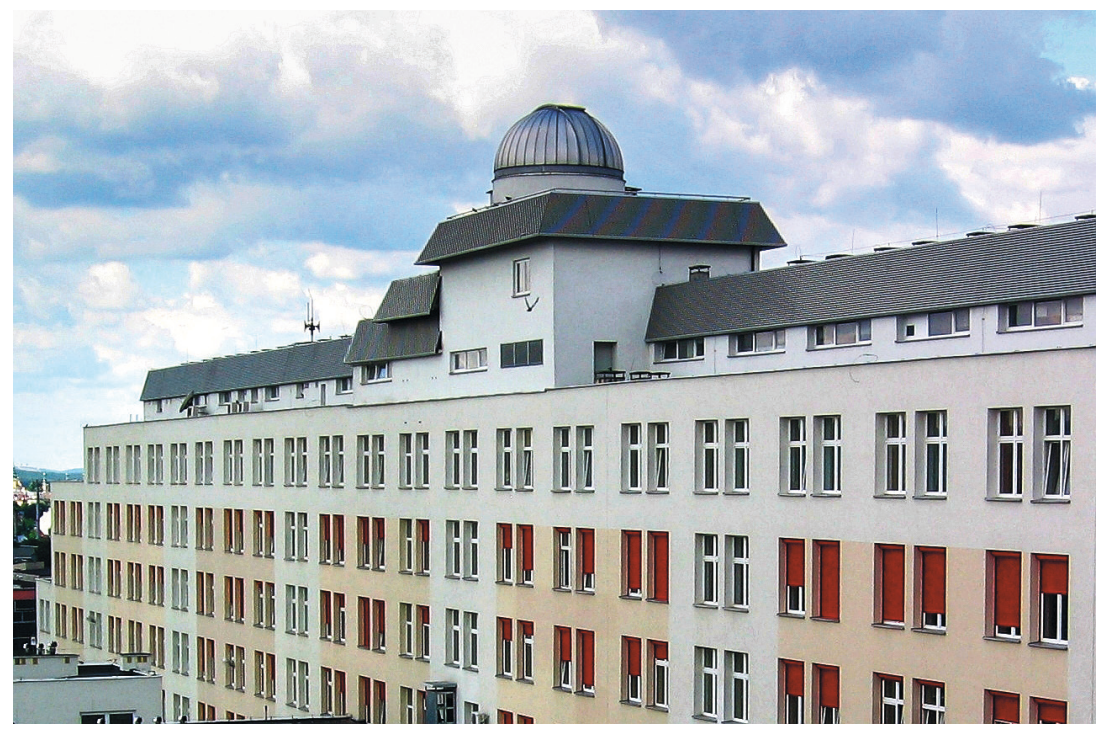

Ryc. 4. Obserwatorium i planetarium na dachu Wydziału Matematyczno-Przyrodniczego UJK. Fot. Krzysztof Maślanka.

Jako początkujący astronom Piotr Flin zajmował się obserwacjami gwiazd zmiennych zaćmieniowych - najpierw jako członek Polskiego Towarzystwa Miłośników Astronomii, w ramach Centralnej Sekcji Obserwacji Gwiazd Zmiennych Zaćmieniowych, później także jako pracownik OAUJ (obserwował minima gwiazd zaćmieniowych w krakowskim Obserwatorium na Forcie Skała).

Późniejsze zainteresowania naukowe Piotra Flina dotyczyły zagadnień związanych z powstawaniem i własnościami wielkoskalowych struktur we Wszechświecie. Badał On m.in. własności gromad i supergromad galaktyk, opierając się na wynikach obserwacji w zakresie promieniowania rentgenowskiego, optycznego i radiowego. Był współautorem (wraz z Janiną Krempeć-Krygier, Bernardem Krygierem i Katarzyną Bajan) obszernej monografii pt. Wtasności struktur wielkoskalowych we Wrechśniecie.

W sumie był autorem lub współautorem co najmniej dwustu pięćdziesięciu publikacji. ${ }^{8}$

8 Zob. Kokowski 2018. 


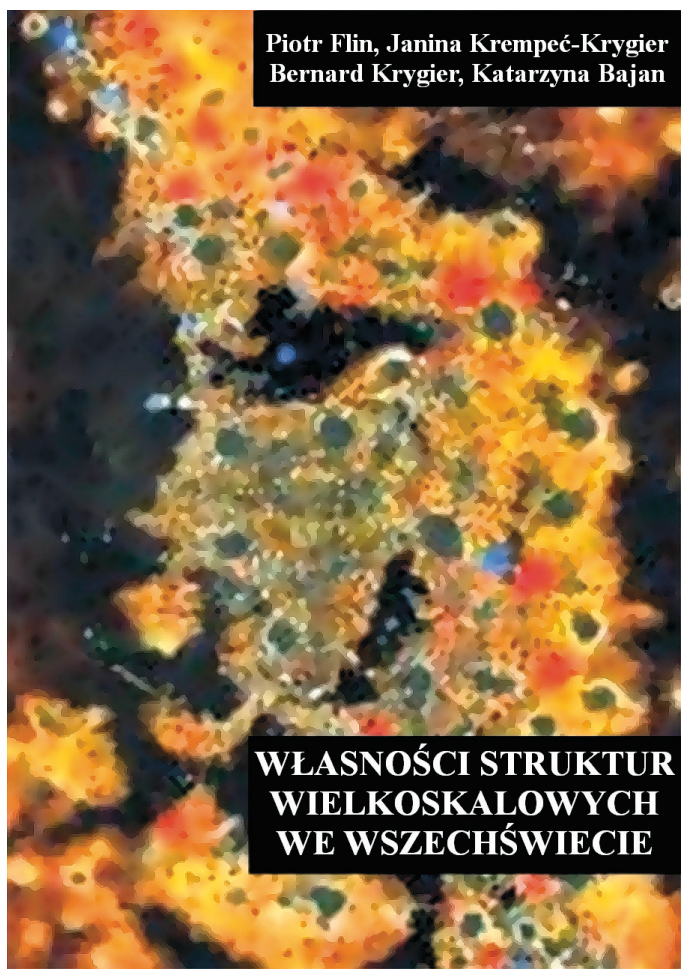

Ryc. 5. Strona tytułowa monografii, wyd. UJK, 2008 r.

\section{Pole Jagiellońskie}

Ważnym wątkiem zainteresowań Piotra Flina była tematyka związana z tzw. Polem Jagiellońskim? . Przypomnę, że w czasie swego pobytu w Pasadenie w Kalifornii na początku lat 60. ubiegłego wieku wspomniany wyżej Konrad Rudnicki, kierując się sugestią sławnego szwajcarsko-amerykańskiego astrofizyka Fritza Zwicky'ego (1898-1974), wybrał niewielki obszar na niebie o rozmiarach (w minutach kątowych) 7,5 × 7,5 szczególnie bogaty w gromady galaktyk. Potem, z pomocą zasłużonego teleskopu systemu Schmidta z Obserwatorium Mount Palomar (średnica zwierciadła $48 \mathrm{cali}=125 \mathrm{~cm}$ ), wykonano serię zdjęć tego obszaru z użyciem filtrów o trzech barwach: niebieskiej, żółtej

\footnotetext{
${ }^{9}$ Maślanka 2016, s. 44.
} 

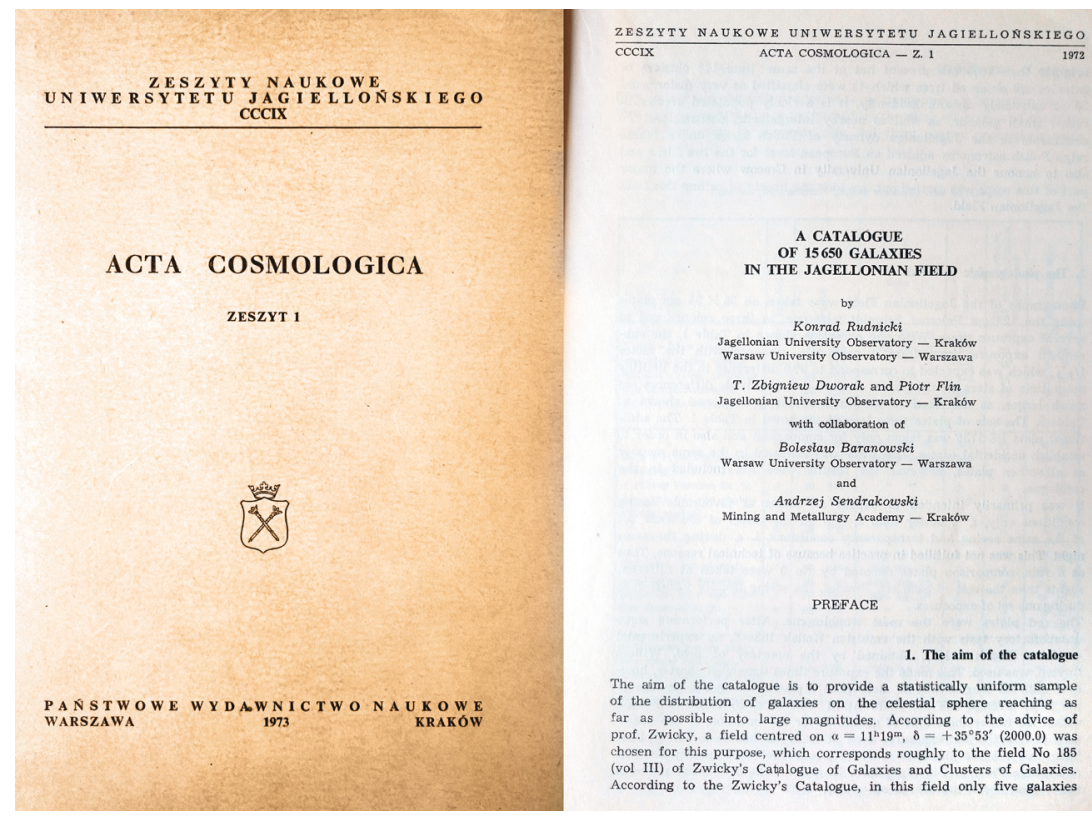

Ryc. 6. Pierwszy zeszyt czasopisma Acta Cosmologica: okładka i początek (jedynego w tym zeszycie) artykułu na temat Pola Jagiellońskiego - zob. Rudnicki et al. 1972.

i czerwonej. W owym czasie był to rekord świata jeśli chodzi o głębokość przeglądu nieba: sięgnięto w nim tak daleko w głąb Wszechświata, jak tylko było to przy ówczesnej technice możliwe. Drewniana skrzynka z cennymi zdjęciami na szklanych płytach o rozmiarach $35 \mathrm{~cm} \times 35 \mathrm{~cm}$ dodarła do Krakowa, gdzie rozpoczęło się żmudne opracowanie. Z czasów studenckich pamiętam kartkę naklejoną na ową skrzynkę z napisem: „Instrukcja dla Pana Celnika”. Były to czasy żelaznej kurtyny i wszechobecnej cenzury; istniała realna obawa, że podejrzliwi celnicy zaczną brutalnie grzebać w szklanych kliszach w poszukiwaniu materiałów wywrotowych i uszkodzą cenny materiał.

Wkrótce potem założono czasopismo, jedyne na świecie poświęcone wyłącznie kosmologii - Acta Cosmologica ${ }^{10}$. Jego pierwszy numer zo-

${ }^{10}$ Ukazały się 22 tomy Acta Cosmologica. W roku 1996 wydawanie czasopisma zostało „zawieszone”, co w praktyce oznacza likwidację. Ówczesny dyrektor OA UJ zarządził, że w dorocznych sprawozdaniach pracowników nie będzie uwzględniał prac tam opublikowanych. 


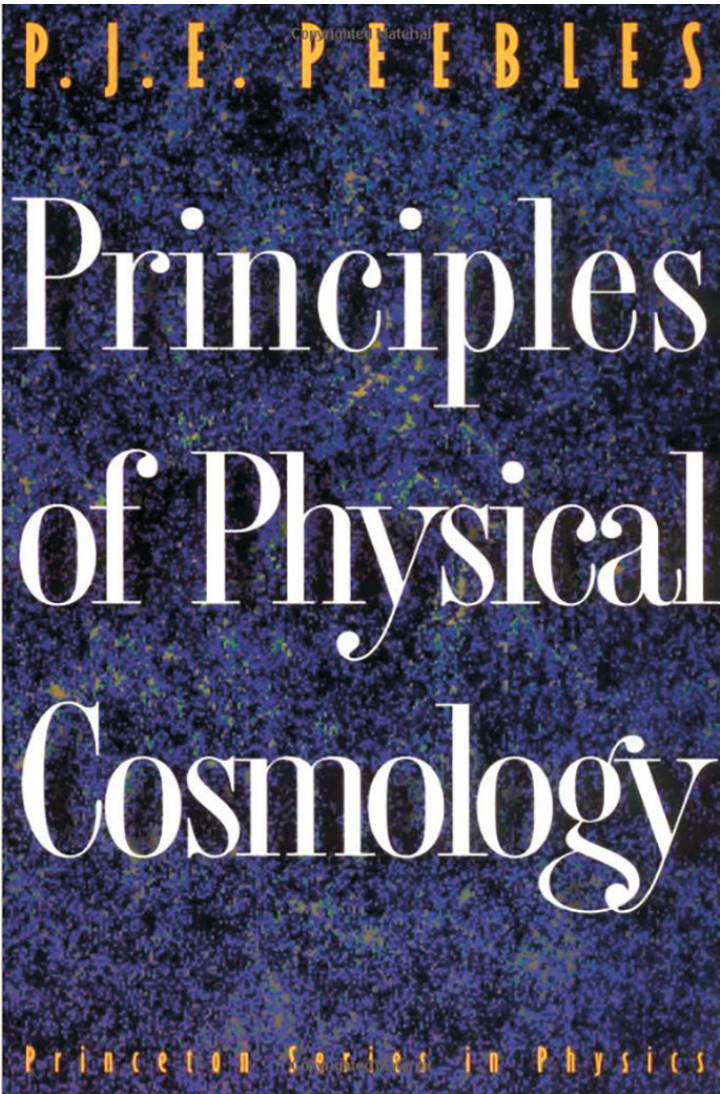

Tests of the depth scaling law in equation (7.54) are shown in figures 7.2 and 7.3. In figure 7.2 (Groth and Peebles 1977, 1986), the triangles in panel (a) are from the Zwicky catalog (Zwicky et al. 1961-68). Redshift samples from this catalog are shown in figures 3.4 and 3.6 , but here we are using the angular distribution of galaxies brighter than a fixed limiting apparent magnitude, $m=15$. The circles are from the deeper Lick catalog in figure 3.9 (Shane and Wirtanen 1967), and the boxes from the still deeper Jagellonian field (Rudnicki et al. 1973). The relative limiting magnitudes in these catalogs are not well calibrated, so the ratio of characteristic sample depths $D_{*}$ is based on the mean densities $\mathcal{N}$ of galaxies per unit area on the sky, and uses the relation $\mathcal{N} \propto D_{*}{ }^{3}$ appropriate to the homogeneous model (eqs. [7.40] and [7.55]). The scaling relation (7.54) says that if in the logarithmic plot in panel (a) the correlation function for one catalog

Ryc. 7. Strona tytułowa i fragment fundamentalnego dla kosmologów-obserwatorów podręcznika Jima Peeblesa (1993, s. 219) cytujący krakowski katalog galaktyk Pole Jagiellońskie. 


\title{
Mapping the Jagiellonian Field of Galaxies
}

\author{
Irina B. Vavilova \\ Astronomical Observatory of the Kiev University, Observatornaya str., \\ 3, Kiev 254053 Ukraine, E-mail: vavilova@rcrm.freenet.kiev.ua \\ Piotr Flin \\ Pedagogical University, Institute of Physics, ul.Lesna 16, Kielce 25-509 \\ Poland, E-mail: sfflin@cyf-kr.edu.pl
}

\begin{abstract}
The analysis of two-dimensional galaxy distribution in the Jagiellonian Field (JF) was carried out by the wavelet technique. The positions of galaxies were taken from the Revised Jagiellonian Field Catalogue (RJFC) based on digitized scans of the JF original photographic plates. We discuss briefly the procedure of star/galaxy separation applied by us to the RJFC, the algorithm and the first results of mapping of the selected parts of the RJFC.
\end{abstract}

\section{What is the Revised Jagiellonian Field Catalogue of Galaxies?}

The region of the original Jagiellonian Field (JF) sky survey (Rudnicki, Dworak, \& Flin 1973) was selected by Zwicky (Zwicky 1962) as a region which is enriched by clusters of galaxies and contains a small number of the brighter galaxies. The JF sky survey (photographic plates in three colors with coordinates of center $\alpha=11^{h} 20^{m}, \delta=+35^{\circ} 26^{\prime}(2000.0)$ taken with the $1.25 \mathrm{~m}$ Palomar Schmidt telescope) coincides with the CGCG field No. 185. The central part of the JF $\left(4^{\circ} \times 4^{\circ}\right)$ was scanned and automatically processed by the COSMOS machine. This procedure allows one to digitize the images on the plate and to receive a set of parameters fitting the inertia ellipse to each image (e.g., Stobie 1980; MacGillivray \& Stobie 1984).

Constructing a modern complete galaxy catalogue in the JF region, we decided to carry out an automated procedure of star/galaxy separation on the digitized images. We experimented with the possible combinations of parameters usually applied for such purposes on similar photographic data (e.g., Hewett 1981; Heydon-Dumbleton, Collins, \& MacGillivray 1989; Odewahn et al. 1992; Weir, Fayyad, \& Djorgovski 1995 with a brief review of discrimination philosophy).

Before applying the procedure, all small objects with the COSMOS area parameter smaller than 60 (in increments) were removed from our sample and about 35,000 objects remained to be analyzed.

Among the possible discriminators only three gave a clear separation of the loci of stars and galaxies. There were plots presenting the dependence on the logarithm of image area denoted as $\log ($ area $)$, the width of Gaussian fit (S) and the intensity weighted second moment $\left(K_{w}\right)$ versus COSMOS image magnitude

(c) Copyright 1997 Astronomical Society of the Pacific. All rights reserved.

Ryc. 8. Strona tytułowa z publikacji Iriny B. Vavilovej i Piotra Flina (1997) na temat Pola Jagiellońskiego.

Źródło: http://adsbit.harvard.edu// full/1997ASPC..125..186V/0000186.000.html. 
stał wydany w roku 1973 w ramach serii Zesayty Naukowe Uniwersytetu Jagiellońskiego, w dość zgrzebnej postaci, na marnym papierze; czytelnik musiał osobiście rozcinać strony. Zawierał on katalog 15650 galaktyk ze wspomnianego obszaru nieba, nazwanego przez krakowskich astronomów „Polem Jagiellońskim”. Jednym z pięciu współautorów tego pionierskiego w skali światowej przedsięwzięcia był Piotr Flin.

Pod taką też nazwą katalog ten wszedł do światowej literatury naukowej (ang. Jagiellonian Field). W swoim podręczniku Principles of Physical Cosmology (1993) cytował go Jim Peebles (ur. 1935), kanadyjsko-amerykański fizyk i kosmolog, skądinąd też bliski przyjaciel Piotra Flina i jego partner w partiach brydża. Trzeba nadmienić, że począwszy od lat 70 . XX w. Peebles jest powszechnie uważany za jednego z wiodących teoretyków jako twórca wielu owocnych idei w dziedzinie kosmologii, a jego wspomniany wyżej podręcznik należy do kanonu dzieł kosmologicznych. Obecnie Peebles piastuje zaszczytny tytuł Albert Einstein Professor Emeritus of Science w Uniwersytecie Princeton.

W oparciu o ten cenny materiał obserwacyjny powstało sporo wartościowych publikacji naukowych cytowanych przez wybitnych znawców problemu gromadzenia się galaktyk. W szczególności, Piotr Flin, przy współudziale innych autorów, opublikował kilka prac wykorzystując materiał ze wspomnianego katalogu:

\section{Ostatnie lata}

Piotr Flin był też aktywnym członkiem Komisji Historii Nauki Polskiej Akademii Umiejętności, a jego zainteresowania historyczne dotyczyły głównie dwóch uczonych: Ludwika Silbersteina (znanego m.in. z polemik z Einsteinem) oraz Tadeusza Banachiewicza (głównej postaci polskiej astronomii pierwszej połowy XX w.).

W uznaniu zasług prof. Flina na Jego cześć nazwano jedną z planetoid odkrytych w Obserwatorium Astronomicznym w Andruszówce na Ukrainie. (ukr. Андрушівська астрономіина обсерваторія-prywatne obserwatorium założone w roku 2001, specjalizujące się w poszukiwaniu planetoid.) Nowej planetoidzie o numerze 296987 nadano imię „Piotrflin”. Obiega ona Słońce z okresem ok. 6 lat po orbicie eliptycznej w odległości wahającej się od 2.5 do 3.9 jednostki astronomicznej. ${ }^{11}$

\footnotetext{
${ }^{11}$ Wikipedia 2018d.
} 


\section{Kilka osobistych wspomnień i refleksji}

Jako uczeń drugiej klasy liceum po raz pierwszy spotkałem Piotra, wówczas magistra astronomii, w roku $1972 \mathrm{w}$ siedzibie krakowskiego oddziału Polskiego Towarzystwa Miłośników Astronomii przy ulicy (wtedy) Ludwika Solskiego 30, gdzie co tydzień o godz. 19 odbywały się popularne prelekcje wygłaszane przez zawodowych astronomów. Ich poziom był zwykle wysoki, natomiast poziom następujących po nich pytań i dyskusji bywał różny. Pierwsze pytanie nieodmiennie zadawał starszy już człowiek, regularny uczestnik tych spotkań, który - niezależnie od tematu referatu - pytał: „Kiedy na Marsa?”.

Mimo wszystko, te sympatyczne spotkania stanowiły dla mnie swoistą odtrutkę na mało intelektualną atmosferę mojego liceum, gdzie dla pewnych nauczycieli najważniejsze były prawidłowo przypięte tarcze szkolne, a dla niektórych uczniów - alkoholowe imprezy i prymitywne, a pretendujące do śmiesznych, wybryki.

Gdy po studiach zostałem asystentem w krakowskim Obserwatorium Astronomicznym UJ dostałem gabinet przylegający do gabinetu Piotra. Stało się to pretekstem do naszych częstych dyskusji o astronomii, a także i polityce. Piotr nie stwarzał żadnych barier, natychmiast zaproponował przejście „na ty”. Jego wypowiedzi były zwykle zwięzłe, a język - barwny i dosadny. W swych poglądach był szczery aż do bólu, co mogło niektórych razić, jednak nie było w tym cienia hipokryzji.

Jakiś rok później, tuż przed stanem wojennym, Piotr przedstawił mnie ks. prof. Michałowi Hellerowi, którego dobrze znał wcześniej z czasów, gdy opracowywano Pole Jagiellońskie. Jak po latach wspominał Heller, praca ta była bardzo żmudna, bez standardowego obecnie wspomagania automatycznego czy cyfrowej obróbki danych:

Pamiętam jak na stole w Obserwatorium Astronomicznym UJ (jeszcze na [ulicy] Kopernika [nr 27]) przez długie miesiące leżały rozpięte mapy Pola Jagiellońskiego, na które ręcznie przenoszono położenia galaktyk z klisz. To były czasy naukowego romantyzmu. Ciemny, przejściowy pokój, chwiejący się stól, stara lampa rzucająca krag światła na ręcznie rysowane mapy. Na stole porzucona linijka i cyrkiel. Tak to zapamiętałem. W ten sposób młody wszechświat ujawniał swoje tajemnice i w ten sposób 
powstał Katalog Jagielloński. Przez szereg [lat] najgłębsze okno w historię wszechświata ${ }^{12}$.

Były to czasy przykręcania śruby przez władzę, a na ten temat mieliśmy poglądy więcej niż zgodne. Pamiętam jak Piotr, wraz z Konradem Rudnickim, aktywnie i odważnie zaangażował się w organizowanie dydaktycznych zajęć zastępczych za kolegę astronoma (z innej uczelni) internowanego w stanie wojennym, by zapewnić ich ciagłość do czasu jego powrotu na uczelnię.

Wkrótce potem, w swoim lapidarnym stylu, oznajmił mi: „Jadę do Michała [Hellera] do Tarnowa. Jedziesz ze mną?’. Miał tam omówić jakieś sprawy naukowe, chyba wspólnej pracy, już nie pamiętam. Propozycja nie do odrzucenia. Pojechaliśmy. Ale dyskusję zdominowała oczywiście - polityka. Był to koniec roku 1982, wszyscy zastanawiali się: „Czy Jaruzelski wpuści naszego Papieża do Polski?”. Pytanie dziś abstrakcyjne, ale wtedy całkiem poważne. Ks. Heller był sceptyczny nie wpuści. Pamiętam spontaniczną reakcję jego Matki: „Michałku, co ty wygadujesz?!’. Jak wiemy, na szczęście, się mylił; Papież przyjechał w czerwcu kolejnego roku 1983.

Piotr miał sporo naukowych przyjaciół za granica, zapewne więcej niż w kraju. Dzięki temu, gdy przyszło zorganizować międzynarodową szkołę kosmologiczną w Polsce z udziałem renomowanych uczonych, to po prostu zwracał się do swoich zagranicznych znajomych z prośbą o przyjazd $z$ referatami.

Kilkakrotnie zapraszał mnie do swego domu na Woli Justowskiej w Krakowie na długie dyskusje oraz wspomnienia w rozległym salonie o ścianach pokrytych grafikami Jego matki. Przez ostatnie lata spotykałem Go też regularnie na posiedzeniach Komisji Historii Nauki PAU ostatni raz chyba w marcu br. Pamiętam, że przy schodach na piętro powiedział mi wtedy: „Idź sam szybciej, bo mnie to trochę zajmie”. Potem dostałem krótki mail (wieczorem 27 III 2018), w którym, dość nieskładnie, najwyraźniej w pośpiechu, pisał:

Drogi Krzysztofie

Piszę aby uprzedzić

Po dzisiejszej wizycie u lekar[za] nie b[e]dę brał udziału

${ }^{12}$ Heller 2017, s. 195. 
w Zebraniu. Trzym[a]j się zdrowo, najlepsze życzenia świąte[c]zne dla Ciebie i Rodziny.

Piotr

Wkrótce potem trafił na sześć długich tygodni do szpitala. Kilka dni po opuszczeniu szpitala, Jego stan zdrowia pogorszył się: wskutek problemów z oddychaniem, konieczne okazało się użycie respiratora i ponowna hospitalizacja, z której już nie powrócił do domu.

\section{6. Śmierć i pogrzeb}

Dr hab. Piotr Flin, astronom, emerytowany profesor Instytutu Fizyki Uniwersytetu Jana Kochanowskiego w Kielcach, zmarł 1 września 2018 r. w Krakowie po ciężkiej chorobie.

Jego pogrzeb odbył się w środę 5 września 2018 r. Urnę z prochami złożono w grobie Jego rodziców oraz zmarłej w dzieciństwie siostry Joasi na Cmentarzu Rakowickim w Krakowie (kwatera XXII B, rząd 15 , miejsce 6$)$.

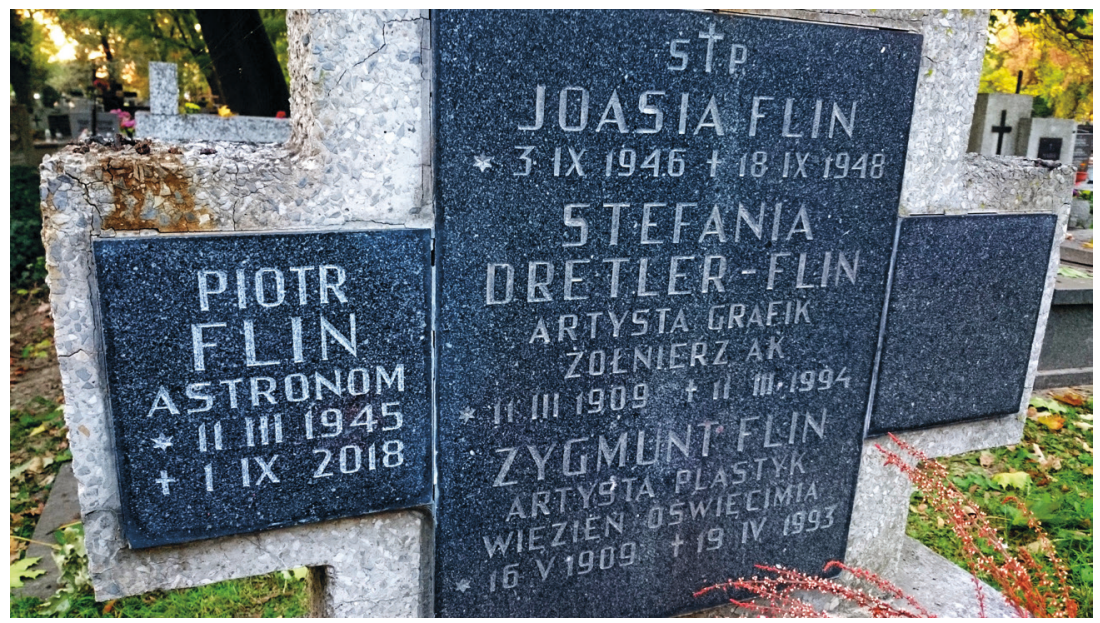

Ryc. 9. Grobowiec rodzinny Flinów na Cmentarzu Rakowickim w Krakowie. Fot. Krzysztof Maślanka. 


\section{Bibliografia}

Artinfo.pl 2018: Zygmunt Flin. Dostęp online: http://www.artinfo.pl/artysta/zygmunt-flin.

Chrzanowska-Pieńkos, Jolanta; Pieńkos, Andrzej 2001: Leksylkon sz̨tuki polskiej XX wieku. Przemierowo: Wydawnictwo Kurpisz.

Flin, Piotr; Bajan, Katarzyna; Biernacka, Monika; Godłowski, Włodzimierz; Juszczyk, Teresa; Panko, Elena; Piwowarska, Paulina 2012: Własności gromad galaktyk. [W:] Wszołek, Kuźmicz, Jamrozy (red.) 2012, ss. 21-30. Dostęp online: https://docplayer.pl/9778006-Czlowiek-i-wszechswiat.html.

Heller, Michał 2017: Partyzant wśród astronomów. [W:] Wszołek, Kuźmicz (red.) 2017, ss. 195-198. Dostęp online: https://docplayer.pl/71310256-Czestochowski-kalendarz-astronomiczny-rok-xiv-redakcja-bogdan-wszolek-i-agnieszka-kuzmicz.html.

Kokowski, Michał 2018: Bibliography of the works by Piotr Flin (1945-2018), an astronomer and exact sciences historian. Studia Historiae Scientiarum 17, ss. 549582. Dostęp online: https://doi.org/10.4467/2543702XSHS.18.022.9342.

Krzyżanowska, Małgorzata Ksenia 2014: Twórczośc grupy Dziewięcin Grafikón (19471960). Polski Instytut Studiów nad Sztuką Świata. Studia i Monografie. Toruń: Wydawnictwo Tako, ss. 422. ISBN 978-83-627-3737-6.

Maślanka, Krzysztof 2016: Konrad Rudnicki (1926-2013) - kilka wspomnień. Analecta. Studia i Materiaty z Driejón Nanki 25/1(48), ss. 43-62.

Nauka Polska. Ludzie Nauki 2018: dr hab. Piotr Flin. Dostęp online: https://nauka-polska.pl/\#/profile/scientist?id $=14584 \& \mathrm{k}=\mathrm{sba3n} 1$.

Naukowe ośrodki astronomiczne w kraju 1976: Postępy Astronomii 3, s. 206. Dostęp online: https://books.google.pl/books?id=3wZqCgAAQBAJ\&pg=PA206.

Peebles, Jim 1993: Principles of Physical Cosmology. Princeton, New Jersey, USA: Princeton University Press. Princeton Series in Physics. ISBN 9780691019338.

ResearchGate 2018: Julian Dretler's scientific contributions. Dostęp online: https://www.researchgate.net/scientific-contributions/2023292491 Julian Dretler.

Rudnicki, Konrad; Dworak, T. Zbigniew; Flin, Piotr; Baranowski, Bolesław; Sendrakowski, Andrzej 1973: A catalog of 15650 galaxies in the Jagiellonian Field. Zesayty Naukowe Uniwersytetu Jagiellońskiego CCCIX. Acta Cosmologica 1, ss. 164.

Vavilova, Irina B.; Flin, Piotr 1997: Mapping of the Jagiellonian Field Galaxies. [W:] Gareth Hunt, H. E. Payne (eds.), Astronomical Data Analysis Software and Systems VI. ASP Conference Series, Vol. 125, 1997, ss. 186-189. Dostęp online: https://www.cv.nrao.edu/adass/adassVI/vavilova.html. 
Wikipedia 2018a: Julian Dretler. Dostęp online: https://pl.wikipedia.org/wiki/Julian Dretler.

Wikipedia 2018b: Akademia Colarossiego. Dostęp online: https://pl.wikipedia. org/wiki/Akademia Colarossiego.

Wikipedia 2018c: Stefania Dretler-Flin. Dostęp online: https://pl.wikipedia.org/ wiki/Stefania Dretler-Flin.

Wikipedia 2018d: Named minor planet “296987 Piotrflin”. Dostęp online: https://en.wikipedia.org/wiki/Meanings of minor planet names: 296001-297000\#987.

Wszołek, Bogdan; Kuźmicz Agnieszka; Jamrozy, Marek (red.) 2012: Człowiek i W sqechswiat. Materialy zinterdyscyplinarnej sesji nankowej "Człowiek. $i$ W szechświat" zrealizowanej dla uhonorowania ksiedza profesora Konrada Rudnickiego w 85 rocznice jego urodzin, Kraków, 15 października 2011. Częstochowa - Kraków: Stowarzyszenie Astronomia Nova, Obserwatorium Astronomiczne Uniwersytetu Jagiellońskiego w Krakowie. Dostęp online: https://docplayer.pl/9778006-Czlowiek-i-wszechswiat.html.

Wszołek, Bogdan; Kuźmicz, Agnieszka (red.) 2017: Czestochowski Kalendarz, Astronomiczny 2017.Częstochowa: Stowarzyszenie Astronomia Nova. Dostęp online: https://docplayer.pl/71310256-Czestochowski-kalendarz-astronomiczny-rok-xiv-redakcja-bogdan-wszolek-i-agnieszka-kuzmicz.html. 